\title{
SPANXB1 wt Allele
}

National Cancer Institute

\section{Source}

National Cancer Institute. SPANXB1 wt Allele. NCI Thesaurus. Code C92965.

Human SPANXB1 wild-type allele is located in the vicinity of Xq27.1 and is approximately 1 $\mathrm{kb}$ in length. This allele, which encodes sperm protein associated with the nucleus on the $\mathrm{X}$ chromosome B/F protein, may play a role in gametogenesis. 